\title{
Determinants of Merchant Participation in Credit Card Payment Schemes
}

\author{
YIING JIA LOKE * \\ School of Social Sciences, Universiti Sains Malaysia
}

\begin{abstract}
This paper aims to empirically establish the determinants of merchant participation in credit card payment schemes. It is found that a merchant's personal background, type of business and total value of sales are significant in determining a merchant's acceptance of cards in payment transactions. Further, it is found that customers' usage of credit cards and other merchants' acceptance of credit cards in payments have a significant influence on a merchant's decision. Findings also indicate that non-pecuniary strategic factors are stronger drivers and barriers to a merchant's participation in credit cards payments services compared to monetary related factors.
\end{abstract}

\section{Introduction}

The payments card industry is characterized as a two-sided market where both the consumers and merchants interact over a common platform. The success of credit card usage depends on the cardholder's decision to choose credit cards over cash when making payments and the extent of merchant acceptance of credit cards as a payment medium.

There are several factors that merchants have to consider when deciding whether to participate in credit card payment schemes. The most obvious factor is the cost. While cardholders have to pay annual fees to banks for their cards, merchants are charged a fee known as merchant discount by the banks to process card transactions. Merchant discount are charged based on the value of transaction. In fact, credit cards are expensive as shown in the study carried out by Food Marketing Institute in the United States noted by Humphrey et al (2003) where it was found that credit cards on average cost supermarkets $0.72 \varnothing$ per transaction compared to $0.12 \varnothing$ for cash. In Malaysia, on average merchant discount is rated at $2 \%$ of the value of transaction and approximately this translates to US\$0.87 (RM3.25) per transaction. ${ }^{1}$ Hence, to cover the cost, some merchants in Malaysia impose a surcharge of $2.5 \%$ to $10 \%$ to the value of transactions, while some impose a minimum value of purchase as low as RM10 to RM300 for credit cards

* School of Social Sciences, Universiti Sains Malaysia, 11800 Minden, Penang, Malaysia. E-mail: yiloke@usm.my. This study was supported by a grant under the Universiti Sains Malaysia Short Term Research Grant, Grant No. 306-PSOSIAL-636027. The author is grateful for the comments by an anonymous referee of the journal. All errors remain mine.

${ }^{1}$ Based on my own calculation using the credit card operations data from Bank Negara Malaysia and the survey conducted with banks regarding charges levied on merchants. 
transactions. ${ }^{2}$ This, however, is against the regulation stipulated by the network providers such as VISA and MasterCard and the banks.

Merchants in Asia and particularly in Malaysia are wary about accepting cards in payments due to the high incidence of credit card fraud cases. According to Chan (2006), the amount of fraudulent credit card cases in Malaysia is valued at US\$5.17 for every US\$100 spent and this is by far the highest among the neighbouring countries such as Singapore, Philippines and Thailand which record US\$1.92, US\$4.81 and US\$0.90 of fraud respectively for every US\$100 spent. ${ }^{3}$ According to Bank Negara Malaysia (2006), the credit card fraud in Malaysia has fallen from RM69.9 million in 2004 to RM18.3 million in 2006.

In general, merchants do not price discriminate between credit card and cash purchasers. Hence, given that merchant has to bear some form of costs and risks, it is puzzling why merchants accept cards in payments transactions. Clearly, there are other factors that outweigh the costs and risks of accepting cards in payments.

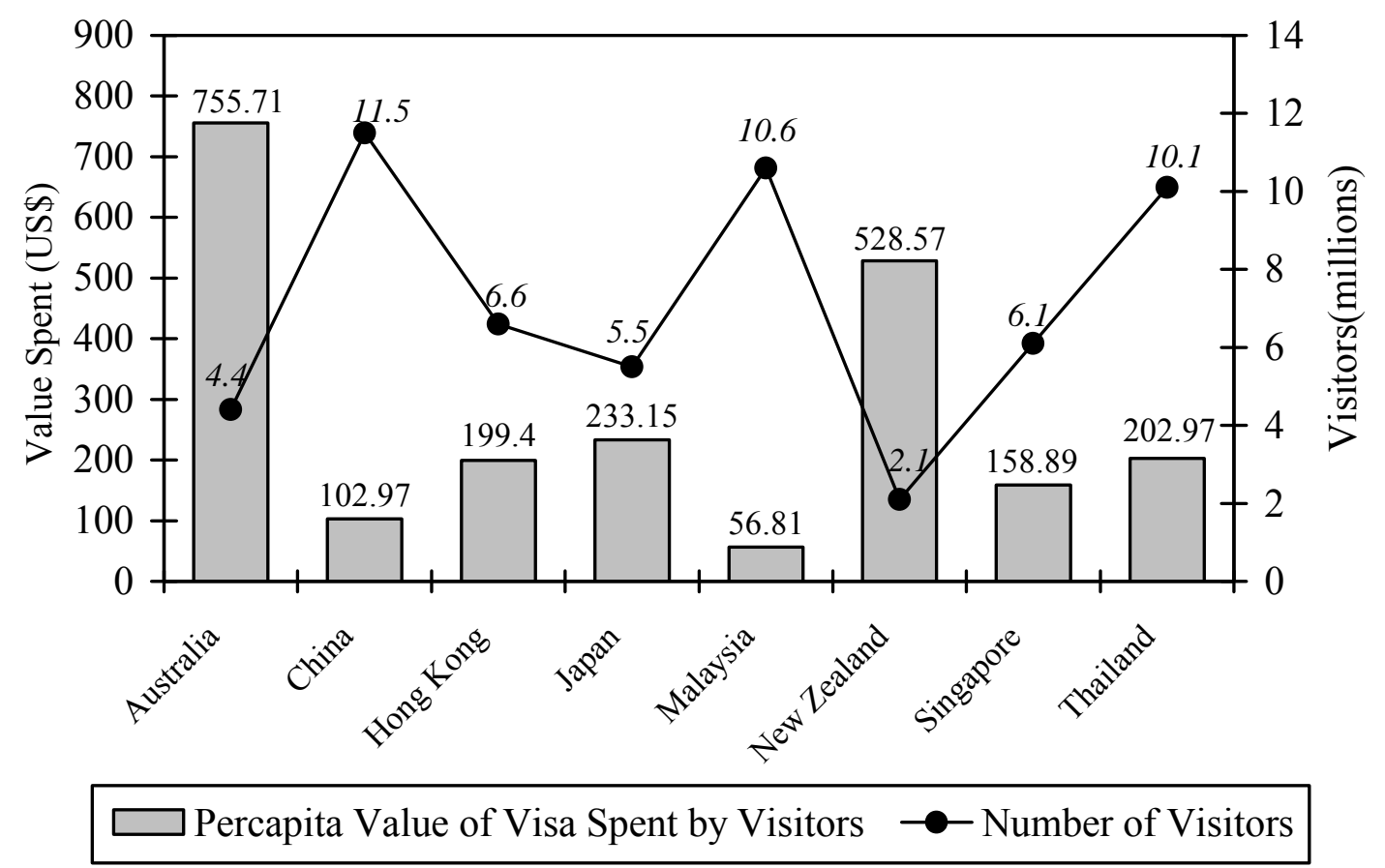

Figure 1: Number of visitors (million) and percapita value of VISA spent in person (US\$) by visitors to the selected countries in $2003{ }^{4}$

\footnotetext{
${ }^{2}$ Merchants that impose surcharge, majority of them impose a 3\% surcharge or a minimum value purchase of RM50 for credit cards payments. This is based on the information collected in this survey.

${ }^{3}$ Prior to the migration to EMV (Europay-MasterCard-Visa) standard, Malaysia received negative media attention for credit card fraud. The credit card fraud figure shown is by far the lowest as credit card fraud has dropped since the migration to EMV standard. Migration to EMV standard was completed at the end of 2005.

${ }^{4}$ Data is obtained from: VISA (2004), Malaysia Tourism Report. It can be accessed at http://www.visaasia.com/ap/center/valueofvisa/industrywatch/includes/uploads/Singapore_Tourism_Report.pdf. The value of spending here refers to the value of spending in person using VISA card.
} 
Figure 1 compares the total value of spending by visitors using VISA card in selected Asia Pacific countries with the number of visitors to these countries. It is interesting to note that while Malaysia has one of the highest numbers of visitors to the country; the per capita spending by visitors using VISA is the lowest among the eight selected AsiaPacific countries. Neighbouring countries such as Thailand and Singapore have higher per capita VISA spending by visitors. Could the lower spending by visitors to Malaysia indicate a low merchant acceptance towards cards transactions in the country?

Figure 2 compares the number of EFTPOS terminals per 1000 inhabitants in selected countries in 2005. EFTPOS terminals are used as a proxy to measure the number of merchants that accepts cards in payments. It is found that besides Thailand, which has the lowest number of EFTPOS terminals per 1000 inhabitants, Malaysia has a rather low EFTPOS network coverage of 3.2 EFTPOS terminals to 1000 inhabitants. In fact, Singapore has 4.3 times more EFTPOS terminals per 1000 inhabitants compared to Malaysia. Corresponding to Figure 1, the lower spending by visitors to Malaysia perhaps is due to the lower merchant acceptance compared to the other countries.

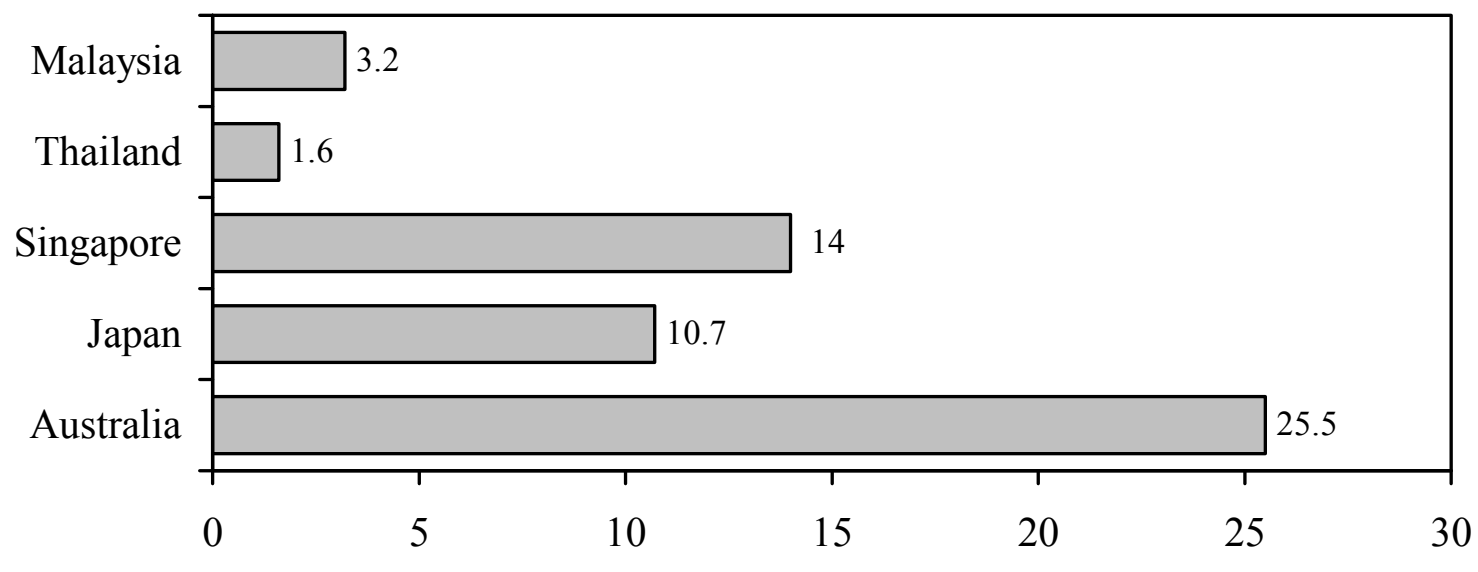

Figure 2: EFTPOS terminal per 1000 inhabitants for selected countries in 2005

Source: Bank Negara Malaysia, Financial Stability and Payments Report 2006; Bank for International Settlements, Payments Systems and Settlements Statistics for Selected Countries (Red Book), 2006, Central Bank of Thailand, Reserve Bank of Australia.

A fundamental understanding on the factors that affect the major players' decision, such as the merchants and the customers, are essential in discussing the credit card industry and its future directions. While there are extensive studies on the usage of credit cards by consumers from various perspectives, less attention is given on merchant's acceptance towards credit cards payments services. Instead, the story on the issuance of credit cards has largely focused on anti-trust matters and the pricing of interchange fees. (see, Evans and Schmalensee, 1999; Rochet and Tirole, 2002; Rochet, 2003; Wright, 2003; and Hayashi, 2006). Existing discussions on merchant acceptance are largely theoretical and have not been empirically tested.

Using the Malaysian data, this study aims to empirically investigate the determinants that affect a merchant's participation in the credit card payment schemes. In the 2006 Malaysia's Budget, it was announced that the government intend to increase the 
acceptance of electronic means of payment. To fully realize this vision, it is critical that a better understanding on the drivers and barriers to the acceptance of credit cards in payments transactions by merchants. In addition, this would also help to enhance financial institutions' marketing strategies on merchant acquisition.

\section{$2 \quad$ Non-cash payments in Malaysia}

Credit cards and charge cards were introduced in Malaysia in the mid-1970s. In the early days, holdings of such payments cards are reserved for the rich. Prior to the introduction of payment cards, cheque is the dominant form of non-cash payment instrument. However, it is only accessible to a small number of consumers and is dominantly used for large value transactions.

By early 1990s, credit cards are more accessible to the general public but there were strict income requirements imposed on credit cardholders. Credit cards applicants must earn a minimum annual income of RM24,000 and are in active employment for three months when application for credit card is submitted. After the Asian crisis in 1997, the Bank Negara Malaysia (central bank of Malaysia) relaxed the income requirement to a minimum of RM18,000 per annum to helped ease liquidity problems among the consumers. In the past one year, the entrants of non-bank credit card issuers have raised the competition further to an already competitive credit card market in Malaysia. The stronger competition among credit card issuers have undoubtedly benefited the consumers as cardholders can now enjoy free for life credit cards, cash back benefits, lower cash advance fee, zero interest instalment plans, flexi pay scheme and $0 \%$ balance transfer. Further, credit cards issuers have introduced several co-branded cards with their business alliances giving consumers more benefits when shopping at selected stores. ${ }^{5}$ As a result of the aggressive marketing and promotion of credit cards, holdings of credit cards have increased significantly by over $178 \%$ from 2000 to 2005, while the credit card financed expenditure has grown by $165 \%$ for the same period. In terms of costs involved in the credit cards payments system, merchant discount ranges from $2 \%$ to $5 \%$ of the total value of transactions, rental of the terminal ranges from RM50 to RM130 and interchange fee is on average $1.2 \% .{ }^{6}$ The merchant discounts and interchange fee has not changed for the past 15 years.

The introduction of debit card in Malaysia is rather unique as it is a by-product of the implementation of Payment Multi Purpose Card (PMPC). The domestic debit and MEPS (Malaysian Electronic Payments System) electronic purse applications are installed in the chip based ATM card or BankCard. With the complete switch from magnetic strip ATM card to the chip based ATM card or BankCard for all domestic banks by October 2003, debit card became accessible to all ATM card holders. Foreign banks followed suit and by March 2004, all ATM cards in Malaysia carry the debit card features. This is clearly reflected in the number of cards in circulation for debit card in Table 1 which explains for the sudden increased in the number of debit cards in 2004 compared to 2003.

\footnotetext{
${ }^{5}$ Store cards that exist in Malaysia are actually loyalty or rewards cards. There are no store cards as defined in the conventional terms.

${ }^{6}$ Source is based on the interviews with selected banks in Malaysia. The interview was conducted in the year 2005 .
} 


\begin{tabular}{llllll}
\hline \hline Payment Cards & 2002 & 2003 & 2004 & 2005 & 2006 \\
\hline Credit Cards & 4357.2 & 5098.0 & 6583.0 & 7815.5 & 8833.0 \\
Charge Cards & 342.1 & 305.6 & 283.6 & 241.4 & 268.3 \\
Debit Cards & N.A. & 2825.4 & 10237.2 & 1576.7 & 18595.1 \\
\hline \hline
\end{tabular}

Table 1: Number of cards in circulation ('000) in Malaysia: 2002-2006

Source: Bank Negara Malaysia. (2007), Financial Stability and Payment Systems Report 2006.

As a result of the incorporation of the debit card feature into ATM cards, the Malaysian debit cards markets see the coexistence of the domestic banks' debit card visà-vis the BankCard and the international brand debit cards. While the use of debit card is gradually increasing in the payment arena with $28.6 \%$ and $33.3 \%$ growth in volume and value of transactions in 2006, the use of charge cards is declining. According to Bank Negara Malaysia (2007), retailers who accept debit cards faced a lower fee compared to the fee charged through the credit cards system. By end of 2005, there are approximately 25,600 retailers that accept debit cards payments. Nevertheless, credit cards remains dominant in terms of payments cards in Malaysia.

Table 2 gives the number of system participants and institutional issuers of the noncash payments instruments in Malaysia.

\begin{tabular}{lllllll}
\hline $\begin{array}{l}\text { Payments } \\
\text { Instruments }\end{array}$ & Institutions & 2002 & 2003 & 2004 & 2005 & 2006 \\
\hline Credit Cards & Banks & 18 & 18 & 17 & 17 & 16 \\
& Non-Banks & 1 & 1 & 1 & 2 & 2 \\
Charge Cards & Banks & 1 & 1 & 1 & 1 & 3 \\
& Non-Banks & 4 & 4 & 4 & 4 & 3 \\
Debit Cards & Banks & 8 & 9 & 13 & 13 & 13 \\
Interbank Giro & Banks & 13 & 14 & 13 & 17 & 16 \\
\hline \hline
\end{tabular}

\section{Table 2: Number of system participants and institutional issuers}

Source: Bank Negara Malaysia. (2007), Financial Stability and Payments Systems Report 2006.

Cash is firmly rooted in people's payment habit with legal tender reinforcing this habit in no small measure. Despite the emergence of payments cards, Malaysia is still a large user of cash in payments. Table 3 compares the use of cash to non-cash payments instruments in Malaysia between 2002-2006 in terms of per capita value. 


\begin{tabular}{lrrrrr}
\hline \hline & \multicolumn{1}{c}{2002} & \multicolumn{1}{c}{2003} & \multicolumn{1}{c}{2004} & \multicolumn{1}{c}{2005} & \multicolumn{1}{c}{2006} \\
\hline Cash in circulation & 974.30 & $1,030.00$ & $1,106.60$ & $1,144.00$ & $1,246.50$ \\
(CIC) & & & & & \\
Cheques & $48,699.80$ & $49,855.10$ & $52,451.10$ & $51,467.00$ & $53,584.90$ \\
Credit Cards & $1,031.70$ & $1,159.6$ & $1,348.6$ & $1,550.10$ & $1,776.50$ \\
Charge Cards & 73.10 & 74.90 & 78.80 & 78.70 & 81.90 \\
Debit Cards & 3.00 & 3.50 & 6.40 & 9.90 & 15.20 \\
Interbank GIRO & 192.70 & 294.50 & 544.50 & 997.30 & $1,700.20$ \\
E-purse & 9.20 & 22.40 & 28.40 & 36.90 & 41.50 \\
\hline \hline
\end{tabular}

Table 3: Per capita value (RM) for selected payments instruments in Malaysia from 2002-2006

Source: Bank Negara Malaysia. (2007), Financial Stability and Payment Systems Report 2006.

There are two main E-purses in Malaysia. One is known as the Touch and Go card, which is largely used, for toll payments and payments for light rail transit while the other is MEPS cash where money can be loaded onto the ATM BankCard for retail payments purposes. A maximum amount of RM2,000 can be loaded onto the ATM BankCard and it can be used to make purchases depending on merchant's acceptance of MEPS Cash in payments. The use of Interbank GIRO accelerated in recent years due to the improved funds transfer mechanism among banks. Consumers popularly use it for bills payments.

\begin{tabular}{llllllll}
\hline \hline & Years & Cheques & $\begin{array}{l}\text { Credit } \\
\text { Cards }\end{array}$ & $\begin{array}{l}\text { Charge } \\
\text { Cards }\end{array}$ & $\begin{array}{l}\text { Debit } \\
\text { Cards }\end{array}$ & E-Purse & $\begin{array}{l}\text { Interbank } \\
\text { GIRO }\end{array}$ \\
\hline Volume & 2002 & 47.71 & 31.41 & 1.93 & 0.25 & 18.55 & 0.15 \\
& 2003 & 35.88 & 26.90 & 1.38 & 0.22 & 35.38 & 0.24 \\
& 2004 & 30.52 & 25.08 & 1.01 & 0.24 & 42.58 & 0.56 \\
& 2005 & 26.02 & 24.01 & 0.81 & 0.27 & 47.44 & 1.35 \\
& 2006 & 23.13 & 24.01 & 0.68 & 0.31 & 49.63 & 2.15 \\
\hline Value & 2002 & 97.38 & 2.06 & 0.15 & 0.01 & 0.02 & 0.38 \\
& 2003 & 96.97 & 2.26 & 0.15 & 0.01 & 0.05 & 0.58 \\
& 2004 & 96.31 & 2.48 & 0.14 & 0.01 & 0.05 & 1.00 \\
& 2005 & 94.81 & 2.86 & 0.15 & 0.02 & 0.07 & 1.84 \\
\hline \hline
\end{tabular}

Table 4: Share of non-cash payments in terms of value and volume of transactions for 2002-2006

Source: own calculation based on the total value and total volume of transactions data from Bank Negara Malaysia. (2007), Financial Stability and Payments Systems Report 2006.

Table 4 compares the share of non-cash payments in terms of volume and value of transactions. Relative to other non-cash payment instruments, cheques dominates especially in terms of value of transactions. This is largely due to the use of cheques for business purposes. In recent years, E-purse dominates in terms of volume of transactions but its share in terms of value of transaction remains very small. However, it is important 
to note that the use of E-purse is dominated by the use of Touch and Go cards for transport related payments only.

\section{$3 \quad$ Model development}

The selection of variables that are likely to affect the participation of merchants in credit cards payment scheme is based on studies by Davis (1989), Rogers (1995), Evans and Schmalensee (1999), Rochet and Tirole (2002), Chakravorti and To (2000), Chakravorti and Shah (2001), Wright (2004) and Hayashi (2006).

Notwithstanding the importance of the perception of merchants about the credit card payment schemes, the scope of this paper limits the analysis of the determinants of merchants' participation in the credit card payment schemes to factors related to the merchant's personal background, the nature of merchant's business and the relevance of network effects. Thus, the factors that affect the merchant's participation in credit card payment schemes can broadly be divided into three categories. The first category relates to the background of the merchant such as his age, his holdings of credit cards measured by the number of credit cards held and whether the merchant is a computer user or otherwise. The latter is to proxy for the merchant's familiarity towards modern technology. The second category is associated with the merchant's business, which includes factors such as type of business, total value of transactions, average value per transaction and the profit margin of his business. The third category measures the influence of other players on the merchant's decision. This is measured by the merchant's perception of customers' card usage and competitors' participation in the credit card payment schemes.

Age of the merchants (in years) is selected with the assumption that differences in age will lead to differences towards the acceptance of technology. Acceptance of credit cards in payments can be considered as a relatively new form of payment technology. Hence, older merchants are expected to be more likely to resist accepting cards from credit card payment schemes than the younger ones. This follows from Zmud (1979) and Assael (1981) who found that older people are expected to be more resistant towards new technology. The number of credit cards held by a merchant suggests that the merchant enjoys the use of credit cards in payments and understands the credit card payment mechanism. As a result, it is expected that such merchants are more likely to accept credit cards. The use of computer(s) by a merchant reflects the merchant's use of technology and this may reflect the acceptance of merchant towards new payment technology such as credit cards. This follows from Hayashi and Klee (2003) that studied the relationship between consumer's choice of payment instrument and usage with the use of technology such as computers. The inclusion of the factors such as number of cards held by merchant and computer usage is also motivated by the concept of perceived ease of use and perceived usefulness as put forth by Davis (1989), Davis et al (1992) and Rogers (1995) in Technology Acceptance Model (TAM).

As a merchant has to pay a merchant discount for accepting cards in payments, the size of merchant's business must be large enough to make it feasible for merchant to do so (Rochet and Tirole, 2002; Chakravorti and To, 2003; Wright 2004). Hence, the total value of transactions, the average value per transaction and profit margin are likely to 
have positive effect on merchant's participation in credit cards payment scheme. Both the total value of transactions and average value per transaction are included in the model as businesses differ in the value per transaction. Some businesses, though are low in value per transaction, generate high total value transactions. This is especially true for businesses in the foods and beverages sector. The business sectors are divided into three groups: non-technical related retail stores, technical related retail stores, and food and beverages sectors. Non-technical related retail stores refers to stores that sell personal goods such as apparels, shoes, fashion accessories, beauty and healthcare products, books and stationeries and etc. Technical related retail stores refers to stores that sell computers and accessories, electrical products, household furnishings, telecommunication products and car accessories. Food and beverages sectors include restaurants, bistros and cafes.

\begin{tabular}{|c|c|c|c|}
\hline $\begin{array}{l}\text { Category of } \\
\text { factors }\end{array}$ & Variables & Description & $\begin{array}{l}\text { Expected } \\
\text { Sign }\end{array}$ \\
\hline \multirow{3}{*}{$\begin{array}{l}\text { Merchant's } \\
\text { background }\end{array}$} & Age & In years & - \\
\hline & Number of personal credit & In quantity & + \\
\hline & Computer user & 1: Computer user; 0 otherwise & + \\
\hline \multirow{9}{*}{$\begin{array}{l}\text { Merchant's } \\
\text { Business' } \\
\text { Characteristics }\end{array}$} & Business Sector 1 & $\begin{array}{l}\text { 1: Non-technical related retail } \\
\text { stores; 0: otherwise }\end{array}$ & + \\
\hline & Business Sector 2 & 1: Technical related retail stores; & + \\
\hline & & $0:$ otherwise & \\
\hline & & (Food and Beverages sector is & \\
\hline & & $\begin{array}{l}\text { the omitted variable for business } \\
\text { sector) }\end{array}$ & \\
\hline & $\begin{array}{l}\text { Total value of transactions per } \\
\text { month }\end{array}$ & In RM & + \\
\hline & Average value per transaction & In RM & + \\
\hline & Profit margin & $\begin{array}{l}\text { 1: Profit margin above } 10 \% \text {; } \\
0 \text { : otherwise. }\end{array}$ & + \\
\hline & Location of business (state) & 1: Penang 0: Kuala Lumpur & - \\
\hline \multirow{2}{*}{$\begin{array}{l}\text { Effects of other } \\
\text { players' } \\
\text { decision via } \\
\text { merchant's } \\
\text { perception } \\
\end{array}$} & $\begin{array}{l}\text { Nowadays, customers prefer to } \\
\text { use cards whenever possible }\end{array}$ & 1: Agree; 0: otherwise & + \\
\hline & $\begin{array}{l}\text { Percentage of merchants in the } \\
\text { same type of business that } \\
\text { accept cards }\end{array}$ & In quantity & + \\
\hline
\end{tabular}

\section{Table 5: Summary of the explanatory variables and hypothesis}

As the usage of credit cards by consumers and acceptance of credit cards by merchants are interdependent, the perception of merchant that customers prefer to use cards whenever possible may provide an impetus for merchants to participate in credit card payment schemes. Further, according to Evans and Schmalensee (1999), the decision by merchant to accept credit cards in payments transactions is partially influenced by the action taken by the merchant's competitors. Therefore, the higher percentage of competitors that accept cards in transactions as perceived by the merchant, the higher the likelihood that the merchant is motivated to participate in the credit card payment schemes. Further, Hayashi (2006) also concluded that monopoly merchant with 
an inelastic demand are more likely to deny cards in transactions. In other words, merchants that have no competitors are less pressured to accept cards.

\section{$4 \quad$ Data}

The data used in this study is collected from a survey conducted on merchants in two major cities in Malaysia - Penang and Kuala Lumpur, from November 2005 to April 2006. The survey is a privately funded and is conducted solely for the purpose of this study. Responses from the merchants are obtained either through a face-to-face interview or a self-administered questionnaire. The questionnaire focuses on credit cards only. The sample includes merchants that accept and do not accept credit cards in payments.

A total of 600 merchants were approached for the study, of which 421 merchants responded. However, only 385 merchants' responses are used in this study as some merchants had reservations in revealing information regarding the total value of transactions and average value of transactions of their business or gave nonsensical values for these two variables.

The merchants are selected based on several requirements. These includes: a) the business total value of transactions per month, b) the business sector, c) the city the business is located and d) if the store is located in a shopping mall or otherwise.

The minimum requirement stipulated by Malaysian acquirers for a merchant to be eligible to accept credit card is to have at least RM20,000 in total values of transactions per month. ${ }^{7}$ Hence, only merchants that meet this requirement were approached. The purpose of this censoring is to capture the information on a merchant's participation in credit card payment schemes from eligible merchants only. This is especially important in investigating why merchants who are eligible to accept credit card choose not to do so.

Merchants are divided into two sectors: the retail trades sector and the food and beverages sector. $65 \%$ of the sample consists of merchants from the retail trade and $35 \%$ from the food and beverage sector, which follows from the Census of Distributive Trades in Malaysia in 2002. This is based on the number of retail trade and restaurant establishments in Malaysia. Retail trade includes non-specialized stores such as the convenience market or large supermarkets and specialized stores, such as computer accessories retail stores, boutiques, furniture and etc. However, in the sample collected, it is found that non-specialized stores make up only $5 \%$ of the total sample for retail trade. As it is of interest to investigate individual stores and small to medium retail stores' acceptance of credit cards in payments, large store chains have been excluded from the survey.

Further, Penang merchants represent $34 \%$ of the sample size and the remainder $66 \%$ represent merchants from Kuala Lumpur. This also follows from the share of total retail trade and restaurant services between Kuala Lumpur and Penang as computed by the Census of Distributive Trades in Malaysia in 2002. Merchants from the main commercial areas in these two cities were approached randomly for the survey.

\footnotetext{
${ }^{7}$ The value varies from acquirers to acquirers and it ranges from RM20,000 to RM100,000 per month.
} 
From a census conducted on the major shopping malls in Penang and Kuala Lumpur ${ }^{8}$, it is found that on average $70 \%$ of merchants located in shopping malls accept credit cards payments. In order to get a better representation of merchants' perception (both the merchants who accept cards and merchants who do not accept cards), the study restricts the sample size of merchants located in shopping mall to not more than $30 \%$ of the overall sample size.

\subsection{Characteristics of survey respondents}

Descriptive statistics of variables in the statistical model are presented in Table 6. Of the 385 total respondents (merchants), 266 merchants (69\%) currently accept credit cards in payments transactions, while 119 merchants (31\%) do not accept credit cards in payments transactions. The average age for merchants who participate in the cards payments scheme ${ }^{9}$ is slightly younger (31 years) compared to those who do not participate in the cards payments scheme (34.2 years). The average age for the total sample was 32 years old. $84 \%$ of the card merchants are computer user compared to only $59 \%$ of non-card merchants who are computer user. Further, on average, card merchants hold more cards ( 1.53 cards) than non-card merchants $(0.82$ cards). This indicates that holdings of cards and usage of computer may have an effect on merchant's participation in cards payments scheme.

On average, card merchants have higher per value of transactions (RM488.74) and total value of transactions (RM163,133.50) than non-card merchants with RM 296.24 and RM 54,341.60 per value of transactions and total value of transactions respectively. This may imply that merchant's volume of business may have an effect on his participation in the credit card payment schemes. $76.7 \%$ of card merchants accept cards in payments transactions because they are in the opinion that customers prefer to use cards in payments whenever possible compared to only $56.3 \%$ of non-card merchants that share the same view. Lastly, on average, card merchants think that $75.9 \%$ of their competitors also offer cards payments services compared to non-card merchants who think only $30.7 \%$ their competitors do so. This suggests that merchants' decision is influenced by their perception on how their customers and their competitors behave. In other words, the merchant's decision is not only influenced by the demand of the customers for cards acceptance but also the supply of merchants that offer similar services.

\footnotetext{
${ }^{8}$ The selected shopping malls in Penang are Kompleks Bukit Jambul, Island Plaza, Gurney Plaza and Prangin Mall. The selected shopping malls in Kuala Lumpur are MidValley, KLCC, Berjaya Times Square, Sungei Wang, Bukit Bintang Plaza, Lot 10 and Starhill.

${ }^{9}$ From henceforth, a merchant who participates in credit cards payments scheme is known as a card merchant while a non-card merchant refers to a merchant who does not participate in credit cards payments scheme.
} 


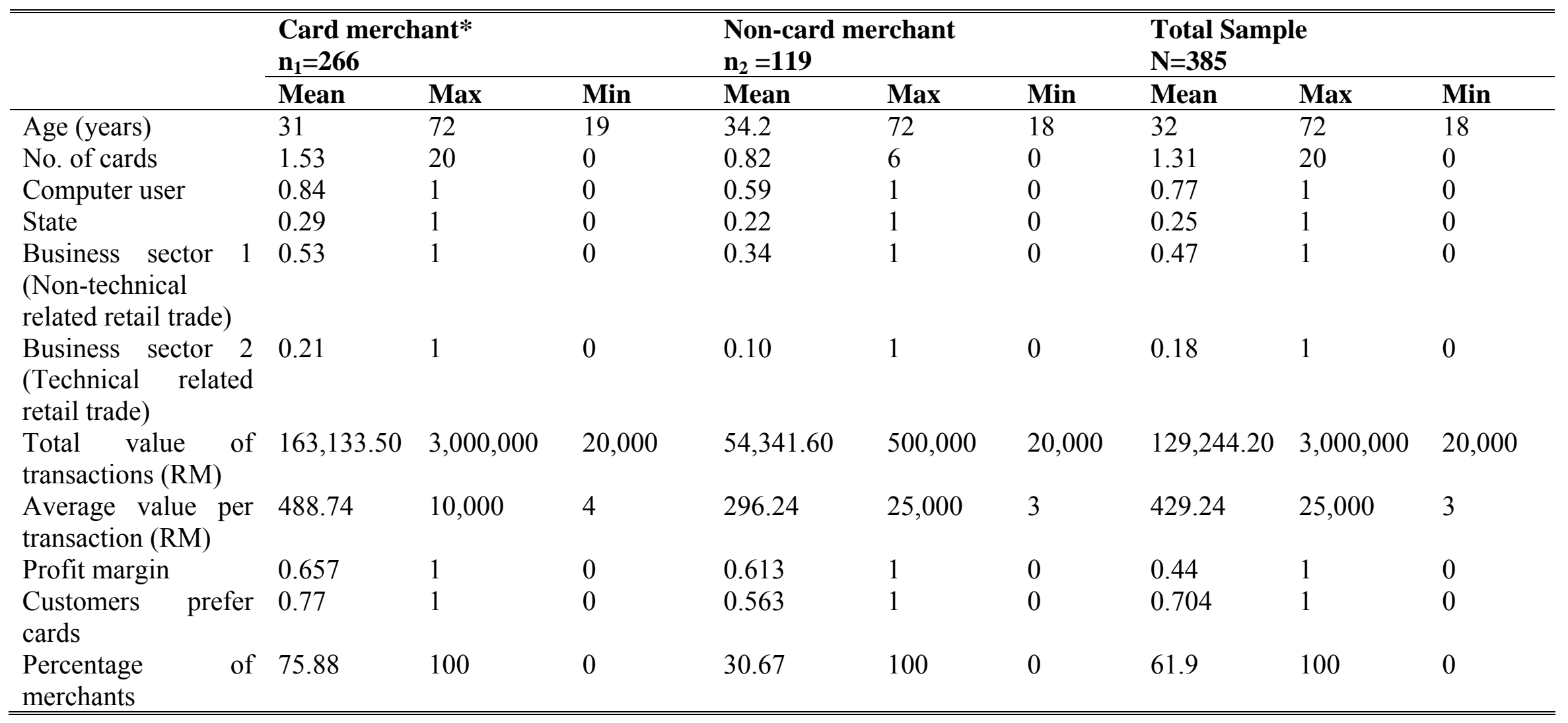

\section{Table 6: Descriptive statistics of variables in the statistical model}

Note: * refers to card merchant refers to merchant that accepts cards in payments transactions while non-card merchant refers to merchant that does not accept card in payments transactions. 
A binary choice logistic regression model is used to analyze the likelihood that a merchant participates in credit card payment schemes given the factors above. The Logit model can be expressed as follows:

$$
\log \frac{\mathrm{P}}{1-\mathrm{P}}=\alpha+\beta_{\mathrm{i}} \mathrm{X}_{\mathrm{i}}+\varepsilon
$$

The dependent variable used in examining the determinants of merchant's participation in credit card payment schemes is measured by a binary dummy variable with value $=1$ if the merchant currently accepts credit cards in payments transactions, and value $=0$, if not. Hence, $\mathrm{P}$ refers to the probability that a merchant accepts credit card and 1-P refers to the probability that a merchant does not accept credit card. $\log (\mathrm{P} / 1-\mathrm{P})$ is the log of odds that a merchant is a card merchant. $\beta i$ are the coefficients of the explanatory variables and $X_{i}$ are the explanatory variables as hypothesized in Table 1. $\varepsilon$ is the stochastic disturbance term of the regression.

\section{The results}

The estimated Logit coefficients (column 1), the odds ratio (column 2) and the associated z-statistics (column 3) are reported in Table 7. The goodness of fit tests for the model indicated that the Likelihood ratio (LR) statistics is 236.5241 , which has a probability value of 0.0000 . Thus, the null hypothesis is rejected and this concludes that the model fits the data well. This is supported by the Hosmer-Lemeshow statistics, which has a value of 11.1660 and a probability value of 0.1925 . This indicates that the null hypothesis is accepted and that the model is good fit. Further, on evaluating the prediction power of the model, it is found that $85.97 \%$ of the prediction of this model is correct. Hence, it can be concluded that the model developed here is a good fit model.

\subsection{Merchant's background}

The relationship between merchant's age and merchant's decision is found to be statistically significant and negative. The negative relationship implies that a younger merchant has a higher probability of accepting credit cards in payments than an older merchant. In considering all observations, the odds that a merchant who is a year older to accept cards is 0.96 times lower than a merchant who is a year younger. In the case where acceptance of credit cards in payments is viewed as a technology adoption decision, the negative relationship between age and merchant's decision is consistent with the study by Zmud (1979) and Assael (1981). Since cash is firmly rooted in payments, due to habit persistence, older merchants may resist new payment technology more than younger merchants (Schreft, 2006). However, age may also affect the kind of business that a merchant chooses to undertake. Certain types of business are more likely to accept credit 
cards than others. ${ }^{10}$ For a given type of business, the interpretation of the effect of age on credit cards acceptance here is on the basis of the relationship between age and technology acceptance.

The number of credit cards held by a merchant has significant positive effect on the likelihood of a merchant's participation in the credit card payment schemes. This implies that for every additional credit card owned by a merchant, the odds that a merchant accepts cards in payments are 1.7 times higher. A merchant that holds more credit cards indicates that the merchant is favourable towards the use of credit cards in payments. Thus, the merchant is more likely to respond positively towards the acceptance of credit cards in payments transactions. The result complies with findings by Davis (1989) and Rogers (1995) on the relationship between perceived usefulness and the adoption of technology.

Unlike the study on the relationship between computer usage and consumer's choice of payments instruments Hayashi and Klee (2003) which was positive and significant, the results in Table 7 indicates that computer usage has a positive but not significant relationship on merchant's acceptance of credit cards in payments. Computer reflects a form of consumer technology and credit card is a form of payment technology. It is assumed that a merchant who is a computer user would be more comfortable with technology, hence would have a positive perception on the use of credit card technology. The assumption follows from the findings by Davis (1989), Davis et al (1992) and Hayashi and Klee (2003).

\subsection{Merchant's business characteristics}

Type of business is found to be a significant determinant in the participation of merchant in credit card payment schemes. Both business sectors 1 and 2, which refer to retail trade sectors, are found to be positive and significant. This implies that retail trade sectors are more likely to accept credit cards in payments than the food and beverages sector.

As the value of transactions in retail goods is on average, higher than food and beverages, it is more likely that consumers spend retail goods on credit than food and beverages. Further, as the credit facilities in credit cards allow financially constrained consumer to spend on credit, to capture sales from financially constrained consumers without being exposed to consumer's default risk, merchants in retail trade have greater incentive to accept credit cards in payments than their counterparts in the food and beverages sector. This finding is consistent with Chakravorti and To (2000).

On comparing the retail sectors (business sectors 1 and 2), it is found that the nontechnical related retail stores are more likely to accept credit cards in payments than technical related retail stores. The odds that non-technical related retail stores to accept credit cards is 1.73 times higher than technical related retail stores. The findings here is somewhat surprising as it was expected that a merchant that sell technical products are more likely to be technologically savvier, hence would be more receptive towards the use of new payment technology such as credit cards. The same also applies to customers that shop in such stores. Further, the average value per transaction in such stores is also higher and the likelihood of customers paying with credit cards than cash would be higher. However, the unexpected findings here may suggest that as retail stores that sell nontechnical personal goods are relatively lower in average value per transaction, impulse purchase by consumers are higher than in retail stores that sell technical products. As a

\footnotetext{
${ }^{10}$ However, in this study, a chi square test shows that there are no significance differences in the business sectors and age of merchants.
} 
result, credit cards are handy and the acceptance of credit cards by merchants would be able to serve such customers well. Further, the frequency of shopping in retail stores that sell non-technical products is also higher than in retail stores that sell technical products.

The total value of transactions per month has a significant and positive relationship with the participation of merchants in credit card payment schemes. As accepting credit cards in payments involves costs such as merchant discount and equipment rental fee, monthly total value of transactions will have an effect on merchant's decision to accept credit cards in payments. Furthermore, acquirers only consider merchants with minimum RM20,000 transactions per month.

There exists a positive relationship between the average value per transaction and the participation of merchant in credit cards payments scheme. However, the relationship is not found to be statistically significant. As merchant discount is imposed on the value of transaction, it is expected that low value businesses would find it less feasible to use credit cards payments technology. This is reflected in businesses such as the fast food chains, which generates high total value of transactions but with low per value transaction. It is rare to find such businesses that accept credit cards in payments transactions.

\begin{tabular}{|c|c|c|c|c|c|}
\hline & $\begin{array}{l}\text { Explanatory } \\
\text { variables }\end{array}$ & $\begin{array}{c}\text { Log of odds, } \\
\beta \\
\text { (1) } \\
\end{array}$ & $\begin{array}{l}\text { Odds, } e^{\beta} \\
(2)\end{array}$ & $\begin{array}{l}\text { Standard } \\
\text { errors } \\
(3) \\
\end{array}$ & $\begin{array}{c}\text { Z-statistics } \\
(4) \\
\end{array}$ \\
\hline Merchant's & Age & -0.037 & 0.964 & 0.0178 & $-2.066^{* *}$ \\
\hline \multirow[t]{2}{*}{ Background } & $\begin{array}{l}\text { Number of cards } \\
\text { held }\end{array}$ & 0.513 & 1.670 & 0.1396 & $1.909 * * *$ \\
\hline & Computer user & 0.266 & 1.305 & 0.3883 & 1.321 \\
\hline $\begin{array}{l}\text { Merchant's } \\
\text { Business }\end{array}$ & $\begin{array}{l}\text { Location of } \\
\text { business (state) }\end{array}$ & -0.390 & 1.477 & 0.4311 & 0.905 \\
\hline \multirow[t]{4}{*}{ Characteristics } & Business sector 1 & 1.737 & 5.679 & 0.3882 & $4.473 *$ \\
\hline & $\begin{array}{l}\text { Business sector } 2 \\
\text { Average value per }\end{array}$ & $\begin{array}{r}1.372 \\
0.00006\end{array}$ & $\begin{array}{l}3.945 \\
1.000\end{array}$ & $\begin{array}{l}0.5524 \\
0.0001\end{array}$ & $\begin{array}{r}2.484 * * \\
0.505\end{array}$ \\
\hline & $\begin{array}{l}\text { transaction } \\
\text { Total value of } \\
\text { transactions }\end{array}$ & 0.00001 & 1.000 & 0.000003 & $3.472 *$ \\
\hline & Profit Margin & 0.088 & 1.092 & 0.3564 & 0.246 \\
\hline \multirow[b]{2}{*}{$\begin{array}{l}\text { Effects of other } \\
\text { players' } \\
\text { decision via } \\
\text { merchant's } \\
\text { perception }\end{array}$} & Customer's effect & 0.740 & 2.097 & 0.3557 & $2.082 * *$ \\
\hline & $\begin{array}{l}\text { Percentage of } \\
\text { merchants in the } \\
\text { same type of } \\
\text { business that } \\
\text { accept cards }\end{array}$ & 0.051 & 1.053 & 0.0059 & $8.654 *$ \\
\hline
\end{tabular}

Table 7: Summary statistics for logit analysis of determinants of merchants' participation in the credit card payment schemes

Note: * significant at $1 \%$ level; ** significant at $5 \%$ level; *** significant at $10 \%$ level.

The coefficient of the profit margin is positively related to merchant's participation in the credit cards payments scheme, though insignificantly. If a merchant has a profit margin higher than $10 \%$, the tendency for the merchant to accept cards in payments transactions is 1.09 times higher than merchant with profit margin less than $10 \%$. As merchants do not price discriminate between cash and credit card purchasers and acquirers on average charge 
$2 \%$ merchant discount, a merchant will only find it profitable to accept card if his business profit margin is more than $2 \%$.

As the study is conducted in two different cities, a location factor is added into the model. It is found that location is a not a significant factor in determining the merchant's decision.

\subsection{Effects of other players' decision via merchant's perception}

The significance of other players' decision on merchant's choice is investigated through the merchant's perception on the preference of customers' medium of payment and the extent of his competitors that offer credit card payment facilities. It is found that other players' decision has a positive and significant effect on merchant's decision to accept credit cards in payments.

The odds for a merchant who agrees that "customers prefer to use credit cards for payments whenever possible" to accept credit cards in payments is 2.1 times higher than a merchant who thinks otherwise. The behaviour of the merchant is consistent with the structure of the credit card payment industry where the success of credit card as a payment medium depends on the interaction between the consumer (cardholder) and merchant (who accepts cards). In other words, a merchant has the incentive to accept credit cards if he thinks that the facility will be well utilized by customers. Further, this also suggests that a merchant is keen to meet customer's needs by offering the type of payment facilities favoured by customers.

Evans and Schmalensee (1999) and Rochet and Tirole (2002) have argued that merchants are pressured to accept cards because customers will be attracted to make purchases from merchant that accept cards as opposed to merchants that do not. On the other hand, Evans and Schmalensee (1999) have also suggested that if a merchant finds that all his competitors accept credit cards, this may indicate to the merchant that his competitors find credit cards acceptance to be profitable, hence the merchant is motivated to follow suit. The findings in this study shows that the higher the percentage of competitors that accept credit cards in payments, as perceived by the merchant, the likelihood for the merchant to follow suit increases. For every additional percentage of competitors that accept cards as perceived by the merchant, the odds for the merchant to participate in credit cards payments scheme increases by 1.05 times. This also implies that a merchant who faces some competition is more likely to participate in the credit cards payments scheme (Hayashi, 2006). Nevertheless, the effect of competitors' actions on a merchant's decision observed in this study does not discount the possibility of business environment and structure on merchants' decisions. In other words, if a business environment and structure favours credit cards acceptance, merchant will respond positively to credit cards acceptance regardless of his competitors' response towards credit card acceptance in payments.

\subsection{Marginal effects of probability}

The study is further expanded to examine the marginal effects of each explanatory variable. Taking the mean output from Table 6 as the typical profile of a merchant, the marginal effect of each of the explanatory variable on the probability that a merchant participates in the credit card scheme can be explained.

The typical profile of a merchant selected here refers to a merchant who is 32 years old, who holds one credit card, is a computer user, owns a retail trade business that sells 
technical products with RM129,200 value of transactions per month, average value per transaction of RM430, has a profit margin above $10 \%$, with business located in Penang, perceives that customers prefers to use cards whenever possible and thinks that $63 \%$ of his business competitors accept cards. The probability for the typical merchant to participate in credit card payments scheme is estimated to be $94.39 \% .{ }^{11}$ Table 8 shows the typical profile of the merchant and the marginal effects of each of the explanatory variable.

\begin{tabular}{|c|c|c|}
\hline Explanatory variable & Typical Sample & $\begin{array}{l}\text { Marginal } \\
\text { Effects }^{12}\end{array}$ \\
\hline Age & 32 & -0.0020 \\
\hline Number of credit cards held & 1 & -0.0141 \\
\hline Computer usage & Computer user & -0.0342 \\
\hline Business Sector & $\begin{array}{l}\text { Technical related retail } \\
\text { trade }\end{array}$ & -0.1338 \\
\hline Total value of transactions per month & RM 129,200 & 0.0000007 \\
\hline Average value per transaction & RM 430 & 0.000003 \\
\hline Profit margin & Above $10 \%$ & -0.0048 \\
\hline Location of business(state) & Penang & 0.0246 \\
\hline $\begin{array}{l}\text { Perception of merchant on customer's } \\
\text { usage of credit cards }\end{array}$ & $\begin{array}{l}\text { Customer prefers to use } \\
\text { cards whenever possible }\end{array}$ & -0.0547 \\
\hline $\begin{array}{l}\text { Perception of merchant on the percentage } \\
\text { of merchants in the same type of business } \\
\text { that accept cards }\end{array}$ & 63 & -0.0027 \\
\hline
\end{tabular}

\section{Table 8: Marginal effects of probability}

To interpret the findings in table 8 , it is observed that when the age of the merchant increases for one year (from 32 to 33 years old), the probability for him to participate in the credit card payment schemes decreases by $0.2 \%$. On the other hand, if the merchant's business is in the foods and beverages sector instead of technical related retail trade, the probability that the merchant will accept cards in payments will decrease by $13.38 \%$. Overall, taking the absolute value of the marginal effects, the results show that type of business has the strongest marginal effects on probability of merchant's participation in the credit card payment schemes. This is followed by the perception of merchants on customer's usage of credit cards. The business' value of transactions both in terms of total

\footnotetext{
${ }^{11}$ The probability for the typical merchant is estimated as follows: $\log \frac{\mathrm{P}}{1-\mathrm{P}}=-3.9506-0.037(32)+0.513(1)+0.2664(1)+1.737(0)+1.372(1)+0.00001(129200)+$ $0.00006(430)+0.088(1)-0.390(1)+0.740(1)+0.051(63)=2.823$. As such as the estimated probability for the typical merchant to participate in credit cards payments scheme would be:

$\mathrm{P}(\mathrm{Y}=1)=\frac{\exp (3.1872)}{1+\exp (3.1872)}=0.9439$.

${ }^{12}$ Marginal effects for continuous variables such as age, number of credit cards held, total value of transactions per month, average value per transaction, percentage of merchants that accepts card are calculated using the following formula: $\mathrm{P}(1-\mathrm{P}) \beta_{\mathrm{i}}$. The marginal effects for dummy variables are the difference of the probability from the typical profile of merchant with the probability taken from the profile of merchant following the change in the associated dummy variable.
} 
value of transactions and average value per transaction have the weakest marginal effect of probability on merchant's participation in credit card payment schemes.

The customers' usage of credit cards has a stronger effect on the merchant's decision than the competitor's. Business value of transaction and profit margin which are indirect measurements to the monetary cost and benefits of participation appear to have weak effect on the merchant's decision.

\subsection{Drivers and barriers to merchant's participation in the credit card payment schemes}

Both card and non-card merchants were asked to choose the most important factor that has affected/will affect their decision to accept cards in payments transactions. It is found that for all merchants, the most important driver to merchants' acceptance of cards in payments is the wish of merchants to meet customers' need.

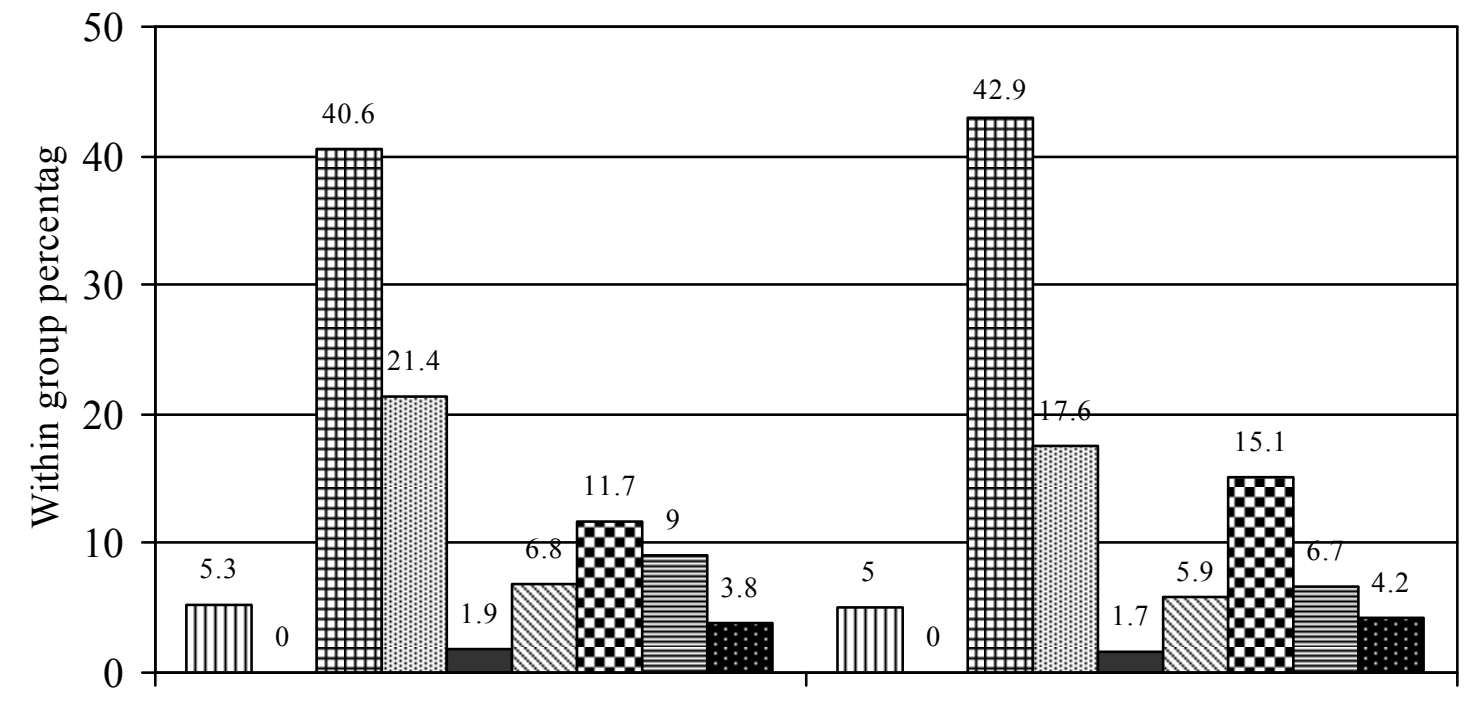

Card merchant

Non-Card Merchant
$\mathbb{W}$ Approached banks/Advertisements
田 Requests from Customers
$\square$ Lower merchant discount
$\square$ Many retailers accept cards
More Cost Effective
영 Friends recommendation
畻 Boost sales
$\mathbb{Q}$ Many benefits of cards payments system
目 Safer than cash

\section{Figure 3: Drivers to merchants’ participation in the cards payments services}

Request from customers seem to be the most important driver to prompt merchants to decide/to consider accepting cards in payments transactions. The second most important driver is the belief of merchants that by accepting cards in payments transactions, it will help draw customer and thus boost their sales volumes. Lastly, peer pressure factor is the third most important driver to merchants in accepting cards in payments. Cost related factors such as lower merchant discount and the cost effectiveness of card do not seem to be an important driver. Less than $4.5 \%$ of card and non-card merchants rated cost effectiveness of card acceptance as an important driver while less than $2 \%$ of card and non- 
card merchant attribute lower merchant discount as an important driver to their participation in credit card payment schemes.

On exploring the barriers to participation in cards payments services by current noncard merchants, these merchants are asked to rank the top three most important factors that have deterred them from offering cards payments services. It is found that the main deterrent is that their sales volume is too low, hence it becomes costly to offer cards payments services. An overwhelming 45\% (54 merchants) of non-card merchants chose this factor as the most important barrier to their reluctance to participate in the credit card payment schemes. Of these 54 merchants, it is found that 34 of the merchants $(62 \%)$ have businesses that have an average per value transaction of less than RM20 and less than RM40,000 of total value of transactions. In other words, although these merchants effectively meet the acquirers' minimum requirement of RM20,000 total value of transactions, the merchants feel that their business volume is not enough to make acceptance of credit cards in payments a viable decision. Further, with the $2 \%$ merchant discount levied on the value of each transaction and with an average value per transaction of less than RM20, card acceptance can be an expensive service to offer to customer. In fact, the cards payments network such as VISA and MasterCard do recognize the cost factor involved in micro payments. Hence, the recent introduction of Visa Wave and MasterCard wave program are targeted to facilitate payments which are not more than RM110 to make cards payments services more cost efficient for micro payments. Of the 54 merchants that claim low sales volume as their main barrier, 51 of them $(94.4 \%)$ have average per value of transaction that is less than RM100.

Further, the lack of customers requesting the facility has also made it redundant for merchant to invest and participate in cards payments services. Hence, if customer do request for such facilities, as shown in Figure 3, it is likely then that the merchants will be persuaded to consider cards payments services. The third factor that is ranked as the most important barrier is related to the cost of participation. Merchants found the cost involved in accepting credit cards payments to be too costly.

Overall, the top three most important factors (as reflected in the total count column) are sales volume that is too low to make acceptance of cards feasible, the lack of customers requesting for such services and thirdly, the cost factor. Table 9 gives the barriers to participation in cards payments services according to its importance.

\begin{tabular}{|c|c|c|c|c|}
\hline Barriers & $\begin{array}{l}\text { Most } \\
\text { important }\end{array}$ & $\begin{array}{l}\text { Second most } \\
\text { important }\end{array}$ & $\begin{array}{l}\text { Third most } \\
\text { important }\end{array}$ & $\begin{array}{l}\text { Total } \\
\text { Count } \\
\end{array}$ \\
\hline Sales volume too low & 54 & 9 & 6 & 69 \\
\hline $\begin{array}{l}\text { Not many customers request the } \\
\text { use of cards }\end{array}$ & 18 & 28 & 25 & 71 \\
\hline $\begin{array}{l}\text { Too costly (merchant discount, } \\
\text { monthly rental fee) }\end{array}$ & 15 & 18 & 20 & 53 \\
\hline Too complicated/not user friendly & 14 & 12 & 21 & 47 \\
\hline Time consuming & 3 & 20 & 22 & 45 \\
\hline $\begin{array}{l}\text { Do not trust the security of the } \\
\text { cards payments system }\end{array}$ & 9 & 9 & 8 & 26 \\
\hline $\begin{array}{l}\text { Delay in payment transfer from } \\
\text { bank }\end{array}$ & 3 & 11 & 9 & 23 \\
\hline Application rejected by bank & 3 & 5 & 3 & 11 \\
\hline
\end{tabular}

Table 9: Barriers to participation in cards payments services 
While the drivers to merchants' participation in credit cards payments services are nonmonetary factors, the barriers to merchants' acceptance of credit cards in payments are monetarily related factors.

\section{Conclusion}

The primary purpose of this paper is to investigate the determinants of merchants' participation in credit card payment schemes. The study limits the determinants to three broad categories namely, the merchant's personal background, the nature of the merchant's business and the influence of customers and competitors on merchant's decision.

In terms of the background of the merchant, it is found that the age of the merchant, the merchant's familiarity towards credit cards payment as measured by the number of cards he holds are found to be significant determinants in merchant's decision. In terms of business characteristics, it is found that business in the retail trade and the total value of transactions have a significant positive effect on the merchant's decision. The use of credit cards by customers and other merchants' decisions on credit card acceptance in payments are found to be significantly relevant in the merchant's decision. A merchant who perceives that most customers prefer to use credit cards whenever possible are motivated to meet customers' need by offering credit cards payments services. Further, the higher percentage of competitors that are perceived to accept cards will induce the merchant to follow suit. Among these determinants, it is found that type of business and usage of cards by customers have strongest marginal effects on the probability of the merchant accepting cards in payments services.

There exists a clear interdependence relationship between the merchant's decision to accept credit cards and the customers' usage of credit cards. This is reflected in the results on the drivers and barriers to merchants' participation in credit card payment schemes. Both the card and non-card merchants rated that "requests from customers" has motivated/will prompt merchants to accept cards in payments while the lack of request from customers for merchants to offer cards payments services poses as one of the top three main barriers to merchant's participation in credit card payment schemes.

"Credit cards help to boost sales" was found to be one of the main drivers to a merchant's acceptance of credit cards while "sales volume too low" was cited as the most important barrier to a merchant's decision on credit card acceptance. These results suggest that besides the total value of transaction, total volume of transaction is also important, as higher total volume of transaction would reduce the total cost per transaction with other factors held constant. Further, from the survey, it is found that $72.5 \%$ of merchants that currently accept credit cards agree that business sales have increased on average by $20 \%$ as a result of accepting credit cards.

Cost related factors are found to be significant as a barrier to merchant's participation in the credit card payment schemes only in businesses with low value per transaction. On further investigation, it is found that only two non-card merchants $(1.7 \%)$ had chosen cost related factors as both the most important driver and barrier to their decision to participate in credit card payment schemes. In other words, this may suggest that if the micro payments programme launched by VISA and MasterCard ${ }^{13}$ recently is able to make

\footnotetext{
${ }^{13}$ In February 2005 and February 2006, Visa Wave and MasterCard Paypass were introduced respectively for micro-payments. These contactless cards are targeted at low value high volume business sectors such as fast
} 
acceptance of cards payments cost effective for low value per transaction businesses, then small scale retailers may find credit cards acceptance a viable decision.

The findings here also revealed that strategic non-pecuniary factors such as merchant's perception on the potential use of credit cards by customers and other merchants' acceptance of credit cards in payments (Rochet and Tirole, 2002), have significant positive influence on merchant's decision. With the introduction of micro payments program, it is important that externalities factors such as the use of credit cards by customers and other merchant's decision on credit card acceptance in payments to be given further attention to better understand a merchant's decision to accept credit cards.

In essence, the paper has established the profile of merchant and business features that are likely to affect merchant's acceptance of credit cards in payments transactions. In the practical sense, the findings on the profile of merchants and business features can serve as a guide for banks' merchant acquisition marketing strategy. The analysis on the relationship between a merchant's perception towards credit cards payments services and his decision to accept cards in payments is beyond the scope of this paper and will be addressed separately.

\section{$8 \quad$ References}

Assael, H. (1981) Consumer Behavior and Marketing Action. Kent: Boston, MA.

Bank Negara Malaysia (2007) Financial Stability and Payment Systems Report, Kuala Lumpur, Malaysia.

Chakravorti, S., and To, T. (1999) "Toward a Theory of Merchant Credit Card Acceptance," Working Paper Series WP: 99-16, Federal Reserve Bank of Chicago.

Chakravorti, S., and Shah, A. (2001) "A Study of the Inter-related Bilateral Transactions in the Credit Card Networks," Federal Reserve Bank of Chicago Policy Studies, EPS 2001-2.

Chan, C.T. (2006) "Credit Card Fraud at a Low," The Star, February 1.

Davis, F. (1989) "Perceived Usefulness, Perceived Ease of Use, and User Acceptance of Information Technology," MIS Quarterly, September, 319-340.

Davis, F. D., Bagozzi, R. P. and Warshaw, P. R. (1992) "Extrinsic and Intrinsic Motivation to Use Computers in the Workplace," Journal of Applied Social Psychology, 22: 11111132 .

Evans, D., and Schmalensee, R. (1999) Paying with Plastic: The Digital Revolution in Buying and Borrowing. MIT Press: Cambridge, MA.

Humphrey, D., Willesson, M., Lindblom, T. and Bergendahl, G. (2003) "What Does It Cost to Make a Payment?" Review of Network Economics, 2: 159-174.

Hayashi, F. and Klee, E. (2003) "Techonology Adoption and Consumer Payments:Evidence from Survey Data," Review of Network Economics, 2: 175-190.

food outlets, supermarkets and petrol stations. The limit of transaction is currently set at RM110. At the moment, these cards can be used at over 7,000 retail outlets (Bank Negara Malaysia, 2007). 
Hayashi, F. (2006) "A Puzzle of Card Payment Pricing: Why Are Merchants Still Accepting Card Payments?” Review of Network Economics, 5: 144-174.

Rochet, J., and Tirole, J. (2002) "Cooperation among Competitors: Some Economics of Payment Card Associations," RAND Journal of Economics, 33: 1-22.

Rochet, J. (2003) "The Theory of Interchange Fees: A Synthesis of Recent Contributions," Review of Network Economics, 5: 1-14.

Rogers, E.M. (1995) Diffusion of Innovations. 4th Edition. The Free Press: New York.

Wright, J. (2003) “Optimal Card Payment Systems”, European Economic Review, 47: 587612.

Wright, J. (2004) “Why Firms Accept Cards?” mimeo, National University of Singapore.

Schreft, S. (2006) How and Why Do Consumers Choose Their Payment Methods? Research Working Papers, The Federal Reserve Bank of Kansas City, RWP 06-04.

Zmud, R.W. (1979) "Individual Differences and MIS Success: A Review of the Empirical Literature," Management Science, 25: 966-979. 